\title{
Percutaneous Nephrolithotomy in Patients with Positive Urine Cultures: Do Complications Increase?
}

\author{
Idrar Kültürü Pozitif Hastalarda Perkütan Nefrolitotomi: Komplikasyonlarda Artış Var mı?
}

\author{
(D) Tufan Süelözgen1, (1) Cemal Selçuk İşoğlu2, (1) Hayal Boyacıoğlu³, (1) Yusuf Özlem İlbey \\ 1 University of Health Sciences, Tepecik Training and Research Hospital, Clinic of Urology, İzmir, Turkiye \\ 2Hakkari State Hospital, Clinic of Urology, Hakkari, Turkiye \\ ${ }^{3}$ Ege University Faculty of Science, Department of Statistics, Izmir, Turkiye
}

\section{What's known on the subject? and What does the study add?}

Regardless of the stone type, there are stone patients with persistant bacteriuria that can not be treated by antibiotherapy. It is known that the presence of uncontrolled bacteriuria in percutaneous nephrolithotomy (PNL) can increase sepsis and similar infectious complications. In this study, it was demonstrated that PNL during antibiotheraphy in patients with persistant bacteriuria is safe in terms of infectious complications. Our study is valuable because it provides information on a topic that is unclear in the literature

\begin{abstract}
Objective: Our aim in this study to determine whether positive urine culture is a risk factor for infectious complications in patients undergoing percutaneous nephrolithotomy (PNL).

Materials and Methods: A total of 958 patients, who underwent PNL in our clinic between 2008 and 2015, were included in the study. The patients were divided into two groups with respect to preoperative urine culture results. Group 1 included 126 patients with nonsterile urine culture. As the control group, 130 patients were randomly selected among patients with preoperative negative urine culture and named as group 2 . The groups were compared in terms of demographic data, postoperative complications and additional interventions.

Results: The mean age was $51.4 \pm 1.05$ years in group 1 was and $48.7 \pm 1.08$ years in group 2 . On postoperative $1^{\text {st }}$ month computed tomography, postoperative residual stone fragments were observed in 27 patients (21\%) in group 1 and 26 patients (20\%) in group 2. The groups were similar in terms of treatment success $(p=0.878)$. No significant difference was found between the groups in terms of postoperative fever $(p=0.46)$, sepsis development and intensive care need $(p=0.733)$.
\end{abstract}

Conclusion: PNL would not increase infectious complications in patients with positive urine culture

Keywords: Urolithiasis, Percutaneous nephrolithotomy, Urine culture

Öz

Amaç: Bu çalışmada amacımız, PNL olan hastalarda pozitif idrar kültürünün enfeksiyöz komplikasyonlar açısından risk faktörü olup olmadığını araştırmaktır.

Gereç ve Yöntem: 2008-2015 yılları arasında kliniğimizde PNL olan 958 hasta çalışmaya dahil edildi. Preoperatif idrar kültürü sonuçlarına göre hastalar iki gruba ayrıldı. Kültüründe üreme saptanan 126 hasta grup 1 olarak adlandırıldı. Kontrol grubu olarak 130 hasta idrar kültürü steril hastalar arasından rastgele seçildi. İki grup demografik veriler, postoperatif komplikasyonlar ve ek girişim gerekliliği açısından karşılaştırıldı.

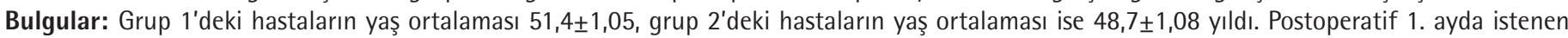
bilgisayarlı tomografide grup 1'de 27 hastada (\%21), grup 2'de ise 26 hastada (\%20) rezidü taş saptandı. Operasyon başarısı açısından iki grup benzerdi $(p=0,878)$. Yine gruplar arasında Postoperatif ateş $(p=0,46)$, sepsis gelişimi ve yoğun bakım ihtiyacı açısından fark izlenmedi $(p=0,46)$.

Sonuç: Pozitif idrar kültürü olup da antibiyotik alırken yapılan PNL enfeksiyöz komplikasyonları artırmamaktadır.

Anahtar Kelimeler: Ürolithiazis, Perkütan nefrolitotomi, İdrar kültürü

Correspondence: Cemal Selçuk Işoğlu MD, Hakkari State Hospital, Clinic of Urology, Hakkari, Turkiye

Phone: +90 4382116067 E-mail: selcukisoglu@hotmail.com ORCID-ID: orcid.org/0000-0002-9999-3908

Received: 17.01.2018 Accepted: 20.03.2018

Cite this article as: Süelözgen T, İşoğlu CS, Boyacıoğlu H, İlbey YÖ. Percutaneous Nephrolithotomy in Patients with Positive Urine Cultures: Do Complications Increase? J Urol Surg 2018;5(2):78-82

बCopyright 2018 by the Association of Urological Surgery / Journal of Urological Surgery published by Galenos Publishing House. 


\section{Introduction}

Percutaneous nephrolithotomy (PNL) is the first treatment option for kidney stones that are $2 \mathrm{~cm}$ and larger in diameter (1). Postoperative fever is the most common complication occurring in $21-39 \%$ of patients and sepsis may develop in $0.3-$ 9.3\% (2). The value of preoperative urine culture in predicting postoperative infection has been investigated (3). Nevertheless, it is currently controversial whether urine culture positivity is a risk factor for infectious complications such as postoperative fever and sepsis (3). In this study, the results of PNL performed in patients with positive urine culture were reviewed and evaluated with a view to determine whether positive urine culture can be recognized as a risk factor for infectious complications.

\section{Materials and Methods}

Data of patients who underwent PNL between 2008 and 2015 were reviewed. Patients younger than 18 years of age and those with urinary tract anomaly were excluded from the study. Study groups were formed with respect to preoperative urine culture results. Group 1 included 126 patients with positive urine culture and antibiogram results. In these patients, appropriate antibiotic treatment was initiated $72 \mathrm{~h}$ before the operation and continued until postoperative fourth day (3). As the control group, 130 patients were randomly selected among patients with preoperative negative urine culture and named as group 2. Intraoperative single dose prophylaxis with $2^{\text {nd }}$ generation cephalosporin was performed in patients of Group 2. All patients underwent preoperative non-enhanced computed tomography (CT) of the whole abdomen. Patients with only one calyx or a pelvic stone were classified as having simple stones, those with one or more calices and pelvis stones or those with staghorn stones were classified as having complex stones (4). The time from the administration of the contrast medium to the patient while in the prone position until the insertion of the nephrostomy catheter was recorded as the operation time. We also recorded the data such as fluoroscopy and operation time, access number and intraoperative complications if occurred. At the end of the operation, a $14 \mathrm{Fr}$ re-entry Malecot catheter was placed in all patients. The Malecot catheter was removed on the postoperative day 1-3. The groups were compared with respect to demographic data, postoperative complications and additional interventions. At postoperative $1^{\text {st }}$ month, all the patients were reassessed routinely by non-enhanced CT. The presence of residual fragments $\leq 4 \mathrm{~mm}$ or a complete clearance of the stones was accepted as treatment success (5). Stone analysis is not covered by the social security institution in our country; therefore, we have insufficient information about stone types in this study. Informed consent was obtained from all patients before surgery.

\section{Statistical Analysis}

In the comparison of two or more groups, the number of subjects in each group should be equal or close to each other. For this reason, we used simple random sampling to determine 130 subjects in the culture-negative group. SPSS package program was used for sampling. A chi-square test was used to evaluate the differences in categorical variables between the groups. The Mann-Whitney $U$ test was used to compare the differences between two independent groups. A $p$ value of $\leq 0.05$ was considered significant. IBM SPSS (Statistical Package for the Social Sciences) software (version 15.00) was used for statistical analysis.

\section{Results}

The data of 958 patients who met the study criteria were reviewed and groups were established. According to demographic data, 39 were male $(31 \%)$ and $87(69 \%)$ were female in group 1; eighty five were male (65\%) and 45 were female $(35 \%)$ in group 2. The number of females was significantly higher in group 1 $(p=0.001)$.

The mean age in group 1 and group 2 was $51.4 \pm 1.05$ years and $48.7 \pm 1.08$ years, respectively. There was no significant difference in mean age between the groups $(p=0.07)$. In group 1, 68 patients were operated on the left kidney and 58 on the right kidney. In group 2, 84 patients were operated due to kidney stones on the left side while 46 patients on the right side. There was no difference between the two groups in terms of the operation site $(p=0.08)$. Of the patients in group 1,82 $(65 \%)$ had simple stones and $44(35 \%)$ had complex stones. In group 2, 74 patients $(56.9 \%)$ had simple stones and 56 patients (43.1\%) had complex stones. In terms of stone burden, the groups were found to be similar $(p=0.2)$. The mean duration of operation was $60.6 \pm 3.1$ minutes in the urine culture-positive group and $65.3 \pm 4.4$ minutes in the urine culture-negative group. There was no significant difference between groups in terms of the duration of operation $(p=0.08)$. The mean duration of fluoroscopy was $151.9 \pm 15.4$ seconds in group 1 and $160.8 \pm 12.2$ seconds in group 2 . The groups were similar statistically in terms of the mean duration of fluoroscopy $(p=0.65)$. The number of accesses performed during the operation was also analyzed between the groups. In the culture-positive group, 111 patients had single access, 13 had two accesses, and 2 patients had three accesses. In the culturenegative group, 117 patients had single access, 11 had two, and 2 patients had three accesses. The two groups were alike in terms of the number of accesses $(p=0.87)$.

Evaluation of the groups in terms of access site revealed that $103(81.7 \%)$ patients in group 1 had subcostal and $23(18.3 \%)$ had intercostal access. In group 2, 111 (85.3\%) patients had 
subcostal and $19(14.7 \%)$ had intercostal access. The groups were found to be similar in terms of access side $(p=0.5)$ (Table 1$)$.

Blood transfusion was performed in 2 patients in group 1 and 1 patient in group 2 due to hemorrhage resulting in intraoperative low blood pressure. The two groups displayed no difference regarding need for intraoperative blood transfusion $(p=0.618)$. No other intraoperative complication except hemorrhage was detected.

In addition, 12 patients (9.5\%) in group 1 and 2 patients (1.5\%) in group 2 received blood transfusion due to postoperative hemodynamic instability. Need for postoperative transfusion was considered grade 2 surgical complication according to the Modified Clavien Classification System. Therefore the two groups showed some difference in the way of postoperative blood transfusion requirement ( $p=0.005)$. Fever over $38^{\circ} \mathrm{C}$ was detected before discharge in 19 patients with positive urine culture and in 15 patients with negative urine culture. The groups were similar in the way of fever $(p=0.46)$. Fever was classified as grade 1 complication. Three patients in group 1 and 4 patients in group 2 required intensive care due to sepsis. They were closely monitored in the intensive care unit and discharged uneventfully. The need for intensive care was considered as Clavien grade 4a and there was no statistically significant difference in sepsis development and intensive care need between the groups $(p=0.733)$. Residual stones were observed in 27 patients $(21 \%)$

Table 1. Significant preoperative and intaoperative data of the patients

\begin{tabular}{llll}
\hline & $\begin{array}{l}\text { Group 1 } \\
(\mathbf{n}=126)\end{array}$ & $\begin{array}{l}\text { Group 2 } \\
(\mathbf{n}=\mathbf{1 3 0})\end{array}$ & $\mathbf{p}$ \\
\hline $\begin{array}{l}\text { Mean age (years) } \\
\text { Gender (\%) }\end{array}$ & 51.4 & 48.7 & 0.07 \\
$\begin{array}{l}\text { Male } \\
\text { Female }\end{array}$ & $39(31)$ & $85(65)$ & 0.001 \\
$\begin{array}{l}\text { Stone burden (\%) } \\
\text { Simple }\end{array}$ & $87(69)$ & $45(35)$ & \\
Complex & $82(65)$ & $74(85.3)$ & 0.2 \\
$\begin{array}{l}\text { Operation time } \\
\text { (minutes) }\end{array}$ & $44(35)$ & $56(14.7)$ & \\
$\begin{array}{l}\text { Fluoroscopy time } \\
\text { (seconds) }\end{array}$ & 60.6 & 65.3 & 0.08 \\
Access site (\%) & 151.9 & 160.8 & 0.65 \\
Subcostal & & & 0.5 \\
Intercostal & $103(81.7)$ & $111(88.6)$ & \\
Number of access & $23(18.3)$ & $19(11.4)$ & \\
One & & & 0.87 \\
Two & 111 & 117 & \\
Three & 13 & 11 & \\
Stone free status (\%) & 2 & 2 & \\
\hline
\end{tabular}

in group 1 and 26 patients (20\%) in group 2. The groups were similar in terms of treatment success $(p=0.878)$. The groups were also evaluated regarding postoperative additional interventions. In the urine culture-positive group, 7 patients (5.5\%) required additional interventions after discharge, 3 patients received a double J stent (DJS) due to discharge from the wound site and severe colic pain, 3 patients underwent ureterorenoscopy (URS), and one patient was kept under observation because of postoperative intermittent hematuria. In one patient, selective angiography revealed arteriovenous fistula and subsequent superselective embolization was performed, and the patient was discharged after embolization without any additional treatment. In group 2, 12 patients required additional interventions. Three patients received a DJS due to discharge from the wound site. URS was performed in 9 patients (9.2\%) because of ureteral calculi ( $p=0.924)$. Additional intervention requirement was classified as grade 3 complication and no significant difference was found between the groups regarding any need for additional intervention ( $p=0.342$ ) (Table 2).

\section{Discussion}

Since Wickham's (6) first series published in 1981, PNL has replaced open stone surgery today almost completely, with high success rates and low complication rates. It is a widely used method which is recognised as minimally invasive and its complications are well known (1). Although post-PNL fever is the most common complication, sepsis and related mortality are rare (1). The CROES study group identified preoperative urine culture positivity as an independent risk factor for postoperative fever (3). Again, el Nahas et al. (7) reported that preoperative positive urine culture is a significant predictor of infectious complications. In their study, Mariappan et al. (8) reported that positive urine culture was not related to the development of infection in the postoperative period. In another study, it was

Table 2. Intraoperative and postoperative complications of the groups

\begin{tabular}{llll}
\hline & $\begin{array}{l}\text { Group 1 } \\
(\mathbf{n = 1 2 6 )}\end{array}$ & $\begin{array}{l}\text { Group 2 } \\
(\mathbf{n = 1 3 0 )}\end{array}$ & $\mathbf{p}$ \\
\hline Intraoperative transfusion (\%) & $2(1.5)$ & $1(0.7)$ & 0.618 \\
& $12(9.5)$ & $2(1.5)$ & 0.005 \\
Postoperative transfusion(\%) & $19(15)$ & $15(11.5)$ & 0.46 \\
Postoperative fever (\%) & $3(2.3)$ & $4(3)$ & 0.733 \\
$\begin{array}{l}\text { Sepsis and requirement for ICU } \\
\text { (\%) }\end{array}$ & & & \\
Additional intervention & 3 & 9 & 0.342 \\
$\begin{array}{l}\text { URS } \\
\text { DJS }\end{array}$ & 3 & 3 & \\
Embolisation & 1 & - & \\
\hline ICU: Intensive care unit, DJS: Double J stent, URS: Ureterorenoscopy & \\
\hline
\end{tabular}


pointed out that mid-stream urine cultures did not reflect the presence and type of bacteria in the upper tract while positive stone culture was significant for postoperative infectious complications and for sepsis (9). Apparently, the predictive value of preoperative urine culture positivity in PNL for postoperative complications is still controversial. The aim of our study was to compare infectious complications such as fever and sepsis between patients who had positive urine culture and accordingly received antibiotherapy $72 \mathrm{~h}$ before the operation until $4^{\text {th }}$ day postoperatively (group 1 ) and patients who had negative urine culture and received a single dose of prophylaxis (group 2). In accordance with the literature (10), we observed that there were more females than males in urine culturepositive group. Other demographic data of the patients showed no difference between the two groups (Table 1). Postoperative fever was detected in 19 patients of group 1 and in 15 patients of group 2, and these patients were treated with broad spectrum antibiotics. Sepsis was detected in 3 patients of group 1 and 4 patients of group 2, and they were treated in the intensive care unit and none of them died from septic shock. There was no statistically significant difference between the groups in terms of fever and sepsis. When the groups were compared in terms of additional interventions, no difference was found between the groups regarding to complications URS, DJS insertion and angioembolization (Table 2). Hemorrhage in PNL is classified as intraoperative, immediate, postoperative, and delayed. Although hemorrhage is common, transfusion need is rare. The rate of transfusion requiring hemorrhage was reported to be $7 \%$ $(0-20 \%)$ in a study (11). In our study, however, it was $9.5 \%$ in group 1 and 1.5\% in group 2. Although our rates of transfusion were not significantly different from the cases in the literature, group 1 displayed a significantly higher rate (Table 2). The rate of treatment success in PNL has been reported to be between $76 \%$ and $84 \%$ (12). In our study, however, it was found to be $79 \%$ in group 1 and $80 \%$ in group 2. There was no difference between the groups in this regard. In addition, our success rates were compatible with the literature (Table 1).

\section{Study Limitations}

The groups could not be compared in terms of co-morbidity because of the retrospective design of the study and the operations were not performed by the same surgeon. Relatively low number of patients was another limitation of our study.

\section{Conclusion}

We may speculate that PNL operations did not increase infectious complications when performed in patients with positive urine culture and treated with relevant antibiotics starting from preoperative 3rd day until postoperative 4th day. Prospective studies with larger patient series are required to conclude with definite judgments on this subject which is still being discussed in the literature.

\section{Ethics}

Ethics Committee Approval: Retrospective study.

Informed Consent: It was taken.

Peer-review: Externally peer-reviewed.

\section{Authorship Contributions}

Surgical and Medical Practices: T.S., C.S.I.., Concept: T.S., C.S.I.., Design: T.S., C.S.I., Data Collection or Processing: T.S., C.S.I., Analysis or Interpretation: H.B. Literature Search: Y.Ö.I., Writing: T.S., C.S.I.

Conflict of Interest: No conflict of interest was declared by the authors

Financial Disclosure: The authors declared that this study received no financial support.

\section{References}

1. Türk C, Petřik A, Sarica K, Seitz C, Skolarikos A, Straub M, Knoll T. EAU Guidelines on Interventional Treatment for Urolithiasis. Eur Urol 2016;69:475-482.

2. Wollin $D A$, Joyce $A D$, Gupta $M$, Wong $M Y C$, Laguna $P$, Gravas $S$, Gutierrez J, Cormio L, Wang K, Preminger GM. Antibiotic use and the prevention and management of infectious complications in stone disease. World J Urol 2017;35:1369-1379.

3. Gutierrez J, Smith A, Geavlete P, Shah H, Kural AR, de Sio M, Amón Sesmero $J H$, Hoznek A, de la Rosette J; CROES PCNL Study Group. Urinary tract infections and post-operative fever in percutaneous nephrolithotomy. World J Urol 2013;31:1135-1140.

4. Tefekli A, Ali Karadag M, Tepeler K, Sari E, Berberoglu Y, Baykal M, Sarilar 0 , Muslumanoglu AY. Classification of percutaneous nephrolithotomy complications using the modified clavien grading system: looking for a standard. Eur Urol 2008;53:184-190.

5. Altunrende F, Tefekli A, Stein RJ, Autorino R, Yuruk E, Laydner H, Binbay $M$, Muslumanoglu AY. Clinically insignificant residual fragments after percutaneous nephrolithotomy: medium-term follow-up. J Endourol 2011;25:941-945.

6. Wickham JE, Kellet MJ. Percutaneous nephrolithotomy. Br Med J (Clin Res Ed) $1981 ; 283: 1571-1572$.

7. el-Nahas AR, Eraky I, Shokeir AA, Shoma AM, el-Assmy AM, el-Tabey NA, Soliman S, Elshal AM, el-Kappany HA, el-Kenawy MR. Factors affecting stone-free rate and complications of percutaneous nephrolithotomy for treatment of staghorn stone.Urology 2012;79:1236-1241.

8. Mariappan P, Smith G, Bariol SV, Moussa SA, Tolley DA. Stone and pelvic urine culture and sensitivity are better than bladder urine as predictors of urosepsis following percutaneous nephrolithotomy: a prospective clinical study. J Urol 2005;173:1610-1614.

9. Shoshany O, Margel D, Finz C, Ben-Yehuda O, Livne PM, Holand R, Lifshitz D. Percutaneous nephrolithotomy for infection stones: what is the risk for postoperative sepsis? A retrospective cohort study. Urolithiasis 2015;43:237242.

10. Viers BR, Cockerill PA, Mehta RA, Bergstralh EJ, Krambeck AE. Extended antimicrobial use in patients undergoing percutaneous nephrolithotomy 
and associated antibiotic related complications. J Urol 2014;192:16671672.

11. Seitz C, Desai M, Häcker A, Hakenberg OW, Liatsikos E, Nagele U, Tolley D. Incidence, prevention, and management of complications following percutaneous nephrolitholapaxy. Eur Urol 2012;61:146-158.
12. de la Rosette J, Assimos D, Desai M, Gutierrez J, Lingeman J, Scarpa R, Tefekli A; CROES PCNL Study Group. The Clinical Research Office of the Endourological Society Percutaneous Nephrolithotomy Global Study: indications, complications, and outcomes in 5803 patients. J Endourol 2011;25:11-17. 